\title{
Assessing Nitrogen and Potassium Deficiencies in Olive Orchards through Discriminant Analysis of Hyperspectral Data
}

\author{
M. Teresa Gómez-Casero, Francisca López-Granados', José M. Peña-Barragán, \\ Montserrat Jurado-Expósito, and Luis García-Torres \\ Instituto de Agricultura Sostenible/CSIC, Apartado 4084, 14080-Córdoba, Spain \\ Ricardo Fernández-Escobar \\ Departamento de Agronomía, Universidad de Córdoba, Apartado 3048, 14080-Córdoba, Spain
}

\begin{abstract}
AdDitional INDEX words. Leaf nutritional status, optimization of fertilization, visible and near-infrared wavelengths
Abstract. Hyperspectral reflectance curves of olive (Olea europaea L.) trees under different $\mathbf{N}$ or $\mathbf{K}$ treatments, and the best wavelengths or vegetation indices to discriminate between different $\mathrm{N}$ or $\mathrm{K}$ applications using discriminant analysis were investigated. Field hyperspectral studies were carried out in two olive orchards located at Cabra and Lucena (southern Spain) for $\mathbf{N}$ and $\mathrm{K}$ experiments, respectively, in 2004 and 2005. At Cabra, olive trees have been fertilized since 1993, and annual applications of $N$ per tree consisted of $0 \mathrm{~kg}$ (N0), $0.5 \mathrm{~kg}$ [N1 (normal)], or $1 \mathrm{~kg}$ [N2 (high)]. At Lucena, olive trees were fertilized since 1997, with $0 \%, 2.5 \%$, and $5 \% \mathrm{~K}_{2} \mathrm{CO}_{3}$. Hyperspectral measurements were collected for each $\mathrm{N}$ and $\mathrm{K}$ treatments using a handheld field spectroradiometer (spectral range, 400-900 nm) in July of both years. To determine the nutritional status, a leaf analysis was carried out in July 2004 and 2005 at both locations. At Cabra, leaf $\mathrm{N}$ concentrations under $\mathrm{NO}$ treatment were below the critical threshold, indicating nutritional deficiencies. Reflectance curves corresponding to N1 and N2 showed higher reflectance values in the near-infrared (NIR) plateau than No treatments. Wavelengths within the NIR region (from $710-900 \mathrm{~nm})$ were selected in both years for discriminating between $\mathrm{N}$ treatments, with an overall accuracy of up to $99.2 \%$. At Lucena, when $K$ was not applied, leaf $K$ content was below the critical threshold, indicating that olive trees were under a nutritional deficiency. Wavelengths from 710 to $890 \mathrm{~nm}$, and the normalized difference vegetation index $\{$ NDVI = $\left[\left(\mathbf{R}_{\mathbf{7 8 0}}-\mathbf{R}_{\mathbf{6 7 0}}\right) /\left(\mathbf{R}_{\mathbf{7 8 0}}+\mathbf{R}_{\mathbf{6 7 0}}\right]\right\}$ were selected for discriminating $K$ treatments with an overall accuracy of up to $94.4 \%$. Classification matrices for cross-validation classified and misclassified cases into the nearest category. The results suggest that the induction of $\mathrm{N}$ or $\mathrm{K}$ nutritional deficiency for more than 10 years in olive trees resulted in different leaf nutrient contents, and this consistently affected hyperspectral reflectance curves, mainly in the NIR region. These results are promising and could provide information for further work on the identification of $\mathrm{N}$ - or $\mathrm{K}$-deficient olive trees using remote sensing.
\end{abstract}

Nitrogen $(\mathrm{N})$ fertilization consistently increases olive yield, although scientific evidence has suggested that annual application is not necessary to obtain good oil productivity (FernándezEscobar et al., 2006). Indeed, fertilizer application has only proved to be beneficial when the leaf nutrient drops below the economic threshold (Hartmann, 1958; Marín and FernándezEscobar, 1997). Traditionally, $\mathrm{N}$ fertilization consists of soil and leaf applications at a uniform rate over all fields without considering any correlation among the amount of fertilizer applied and tree production or the spatial variability in the N nutrient. Farmers do not usually fertilize with potassium (K), although Restrepo (2006) and Arquero (2004) demonstrated that applications of $2.5 \% \mathrm{~K}$ allow reaching an optimum productivity and a better tolerance to a drought season, which is very frequent under our Mediterranean conditions. Leaf nutrient analysis carried out in July is the best method for diagnosing tree nutritional status and for determining future recommendations (Benton Jones, 1985; Fernández-Escobar et al., 1999).

Received for publication 23 Jan. 2007. Accepted for publication 27 Mar. 2007. This research was partially funded by the Spanish Ministry of Education and Science (R\&D projects: AGL2005-06180-CO3-02 and AGL2005-3273). A Ramón y Cajal contract supported the research of Montserrat Jurado-Expósito. We thank Hermann Restrepo for his technical assistance in $\mathrm{N}$ and $\mathrm{K}$ foliar analysis.

${ }^{1}$ Corresponding author. E-mail: flgranados@ias.csic.es.
López-Granados et al. (2004) demonstrated the strong spatially aggregated distribution of both nutrients by using geostatistics. They designed site-specific fertilizer application maps according to the $\mathrm{N}$ and $\mathrm{K}$ fertilization thresholds and reported savings of $97 \%$ and $83 \%$, and of $70 \%$ for $\mathrm{N}$ and $\mathrm{K}$, respectively. However, mapping nutrients for predicting $\mathrm{N}$ management based on leaf sampling and foliar analysis is time-consuming and expensive. Remote sensing may be more efficient than field measurements. To detect and map nutrient status it is necessary for suitable differences to exist in the foliage spectral reflectance (Haboudane et al., 2002). Thus, a considerable research effort is being carried out both to study the reflectance pattern of crop $\mathrm{N}$ deficiencies (Alchanatis and Schmilovitch, 2005; Graeff et al., 2001; Osborne et al., 2002), and to translate remotely sensed information into accurate $\mathrm{N}$-specific recommendations (Scharf et al., 2002). The research on the potential of using remote sensing techniques to detect $\mathrm{K}$ and other nutrient deficiencies is much more limited. The visual symptoms for $\mathrm{K}$ deficiencies in olive trees are characterized by increased darkening of the foliar surface followed by the presence of red patches, which are succeeded by necrosis of the leaf borders (Fernández-Escobar, 1999). Ponzoni and Gonçalves (1999) induced K deficiency symptoms in Eucalyptus saligna $\mathrm{Sm}$. seedlings and concluded that the symptoms related to $\mathrm{K}$ deficiencies were detected more easily by using 
spectral data in the visible region of the spectrum. Fridgen and Varco (2004) studied the in-season assessment of cotton (Gossypium hirsutum L.) leaf $\mathrm{N}$ and $\mathrm{K}$ concentrations and reported that variations in $\mathrm{N}$ fertilizer rates induced a chlorophyll concentration increase in leaves, but no consistent effect on the chlorophyll concentration was observed when increasing $\mathrm{K}$ nutrition. To our knowledge, there is no information about the detection of $\mathrm{N}$ and $\mathrm{K}$ deficiencies in olive groves to predict fertilization needs.

Current technological advances suggest satellites using hyperspectral sensors, but it is crucial to explore first the potential for identifying small or local variations in absorption features in the spectra by using hyperspectral sensors in a handheld spectroradiometer (Karimi et al., 2005b; Koger et al., 2004; Schmidt and Skidmore, 2003). To predetermine a subset of narrow wavelengths without losing any important information, several statistical methods have been used. For instance, artificial neural networks in corn (Zea mays L.) (Goel et al., 2003) and wheat (Triticum aestivum L.) (Wang et al., 1999); decision tree technology in corn (Goel et al., 2003); multivariate data analysis methods like principal components; and discriminant analysis in tomato (Lycopersicon esculentum Mill.), wheat, and corn (Girma et al., 2005; Karimi et al., 2005a, b; Slaughter et al., 2004) have been used.

Spectral reflectance differences can be enhanced by using vegetation indices, which are mathematical (ratios or linear) combinations between bands or selected wavelengths, when multispectral or hyperspectral data are being used. They take advantage of the vegetation reflectance contrast between different wavelengths. Those most widely used in multispectral remote sensing research for detecting and quantifying vegetation are the normalized difference vegetation index [NDVI = $(\mathrm{NIR}-\mathrm{R}) /(\mathrm{NIR}+\mathrm{R})$, where NIR is near-infrared, and $\mathrm{R}$ is red (Rouse et al., 1973)], and the ratio vegetation index [RVI (NIR/ R) (Jordan, 1969)]. The NDVI and RVI indices are commonly used to differentiate vegetation because the latter usually shows a high reflectance in NIR and a low one in $\mathrm{R}$, and both indices enhance these differences (Elmore et al., 2000; Hansen and Schjoerring, 2003; Jackson and Huete, 1991; Koger et al., 2004). Some other authors have studied $N$ detection with combinations of hyperspectral wavelengths from visible and IR regions because these indices may give a more accurate estimation of biophysical parameters such as leaf $\mathrm{N}$ concentration. Xue et al. (2004) found that the ratio index of NIR-togreen wavelengths $\left(R_{810} / R_{560}\right.$, being $R$ reflectance to this wavelength) could be useful for nondestructive monitoring of $\mathrm{N}$ status in rice (Oryza sativa L.) plants. Ferwerda et al. (2005) combined all wavebands between 300 and $2500 \mathrm{~nm}$ for predicting $\mathrm{N}$ content of five plant species and reported that high correlations occurred between 300 and $700 \mathrm{~nm}$, and mean $\mathrm{N}$ content in olive trees.

Currently, Spanish farmers are making considerable investments (e.g., drip irrigation, no-tillage techniques, and mechanized harvesting) to obtain modern olive orchards. They realize that for sustainable production and good net returns, sitespecific fertilization based on maps from remote sensing approaches may have potential. Canopy hyperspectral reflectance analysis is the first step in evaluating this potential. The objectives of this study were 1) to determine the hyperspectral reflectance curves of olive trees with different $\mathrm{N}$ or $\mathrm{K}$ leaf content, 2) to select the best hyperspectral wavelengths or vegetation indices to discriminate between different $\mathrm{N}$ and $\mathrm{K}$ applications applying discriminant analysis, and 3) to establish the misclassification percentage and validate the classification accuracy of this analysis by using the "one-data out" approach for cross-validation. These objectives would provide information to integrate it in remote sensing studies for precision fertilization in olive orchards.

\section{Materials and Methods}

STUDY SITES AND FERTILIZATION DESIGN. Field hyperspectral studies were carried out in two nonirrigated olive orchards located at Cabra and Lucena (two locations $8 \mathrm{~km}$ apart in Córdoba, southern Spain) for $\mathrm{N}$ and $\mathrm{K}$ experiments, respectively, in 2004 and 2005. At Cabra, 14-year-old 'Picual' olive trees spaced at $7 \times 7 \mathrm{~m}$ have been fertilized since 1993, following two different $\mathrm{N}$ applications: soil (S) and soil plus foliar (SF) applications using urea $(46 \% \mathrm{~N})$ as the source of N. Soil applications consisted of 0 (N0), 0.5 (N1, normal), or 1 (N2, high) kg N/tree annually at mid March; and SF applications consisted of $0,0.5$, or $1 \mathrm{~kg} \mathrm{~N} /$ tree and year distributed as $50 \%$ to the soil and $50 \%$ foliar application at a concentration of $4 \%$ from April to October, depending upon the amount to be applied (Table 1). At Lucena, 50-year-old 'Hojiblanca' olive trees spaced at $9 \times 9 \mathrm{~m}$ have been fertilized since 1997, with 0 (K0), 2.5\% (K2, normal), and 5\% (K2, high) $\mathrm{K}_{2} \mathrm{CO}_{3}$. Experiments were designed as a split plot $(2 \times 5)$ with four blocks in Cabra, with the form of application ( $\mathrm{S}$ or SF) the whole-plot factor and $\mathrm{N}$ dose the subplot factor, and as completely randomized blocks with four replicates in Lucena. The olive tree is strongly alternate bearing, with 2004 being an "off" year and 2005 an "on" year. This agronomic phenomenon has been demonstrated to have a strong influence on leaf nutrient concentrations, as reported by Fernández-Escobar et al., (1999). A similar annual rainfall was recorded in both locations: 684 and $450 \mathrm{~mm}$ in 2004 and 2005 respectively.

LEAF ANALysis. To determine the nutritional status, a leaf analysis was carried out in leaf samples collected from every experimental unit in July 2004 and 2005 in both locations. Each leaf sample comprised four subsamples of 25 healthy, fully expanded mature leaves collected from the middle portion of current-season shoots, about $1.5 \mathrm{~m}$ above the soil surface, at the four cardinal points from every olive tree in mid July in 2004 and 2005. These four subsamples were mixed in paper bags to provide a bulked sample with 100 leaves to ensure that it was representative of the surrounding area. The leaves were taken to the laboratory in portable coolers and washed with deionized water, dried at $80{ }^{\circ} \mathrm{C}$ for $2 \mathrm{~d}$, and finally ground to pieces of $0.5 \mathrm{~cm}$. Nitrogen was analyzed by Kjeldahl digestion, and $\mathrm{K}$ by using a 1.100B atomic absorption spectrometer (Perkin Elmer Corp., Norwalk, CT), after which the leaf samples were reduced to ash in a muffle furnace at $600{ }^{\circ} \mathrm{C}$ for $12 \mathrm{~h}$ and dissolved in $0.1 \mathrm{~N} \mathrm{HCl}$. Analyses of variance were performed on the data for statistical comparison.

The fertilization threshold of every leaf nutrient (i.e., the nutrient limit for the sufficient range) was estimated at $\mathrm{N} \geq$ $1.5 \%$ and $\mathrm{K} \geq 0.8 \%$ (Fernández-Escobar, 1999).

HYPERSPECTRAL FIELD DATA. On 18 and 19 July 2004 and 2005, 20 hyperspectral measurements were collected for each $\mathrm{N}$ and $\mathrm{K}$ treatment per tree. Measurements were collected using an ASD Handheld FieldSpec Spectroradiometer (Analytical Spectral Devices, Inc., Boulder, CO) under sunny conditions between 1200 and $1400 \mathrm{HR}$ (Salisbury, 1999). A telescopic 
Table 1. Nitrogen $(\mathrm{N})$ and potassium (K) application rates, methods, and calendar since 1993 and 1997 to 2005 , respectively, and leaf N and K contents for each treatment in olive trees.

\begin{tabular}{|c|c|c|c|c|c|c|c|c|c|c|}
\hline \multirow[b]{3}{*}{ Location (nutrient) } & \multirow[b]{3}{*}{ Treatment } & \multicolumn{7}{|c|}{ Calendar of treatments } & \multirow{2}{*}{\multicolumn{2}{|c|}{$\begin{array}{l}\text { Mean leaf nutrient } \\
\text { content (mg/leaf) }\end{array}$}} \\
\hline & & \multirow{2}{*}{$\begin{array}{l}\text { Mid } \\
\text { March }\end{array}$} & \multirow{2}{*}{$\begin{array}{l}\text { Mid } \\
\text { April }\end{array}$} & \multirow{2}{*}{$\begin{array}{l}\text { Mid } \\
\text { May }\end{array}$} & \multirow{2}{*}{$\begin{array}{l}\text { Mid } \\
\text { June }\end{array}$} & \multirow{2}{*}{$\begin{array}{l}\text { Mid } \\
\text { July }\end{array}$} & \multirow{2}{*}{$\begin{array}{c}\text { Mid } \\
\text { September }\end{array}$} & \multirow{2}{*}{$\begin{array}{c}\text { Mid } \\
\text { October }\end{array}$} & & \\
\hline & & & & & & & & & 2004 & 2005 \\
\hline Cabra, Spain (N) & N0 ${ }^{y}$ & & & & & & & & $1.40 \mathrm{a}^{\mathrm{x}}$ & $1.30 \mathrm{a}$ \\
\hline & N2 & $0.5 \mathrm{~S}$ & $0.5 \mathrm{~S}$ & & & & & & $1.88 \mathrm{c}$ & $1.50 \mathrm{~b}$ \\
\hline & Noy & & & & & & & & $1.64 \mathrm{a}$ & $1.40 \mathrm{a}$ \\
\hline & N1 & $0.25 \mathrm{~S}$ & $0.1 \mathrm{~F}^{\mathrm{w}}$ & & $0.1 \mathrm{~F}$ & & $0.1 \mathrm{~F}$ & & $1.90 \mathrm{~b}$ & $1.53 \mathrm{~b}$ \\
\hline Lucena, Spain (K) & $\mathrm{K} 0^{\mathrm{v}}$ & & & & & & & & $0.54 \mathrm{a}$ & $0.43 \mathrm{a}$ \\
\hline \multirow[t]{2}{*}{$(\mathrm{ST} \geq 0.8 \%)$} & $\mathrm{K} 1$ & & $5.25 \mathrm{~F}$ & & & $5.25 \mathrm{~F}$ & & & $0.90 \mathrm{~b}$ & $0.60 \mathrm{~b}$ \\
\hline & $\mathrm{K} 2$ & & $10.5 \mathrm{~F}$ & & & $10.5 \mathrm{~F}$ & & & $0.97 \mathrm{~b}$ & $0.61 \mathrm{~b}$ \\
\hline
\end{tabular}

${ }^{\mathrm{z}}$ Critical threshold.

${ }^{\mathrm{y}} \mathrm{N} 0, \mathrm{~N} 1$, and $\mathrm{N} 2=0,0.5$, and $1 \mathrm{~kg} \mathrm{~N} /$ tree respectively (urea, $46 \% \mathrm{~N}$ ).

${ }^{\mathrm{x}}$ Letters indicate mean separation for each application method within each year at $P \leq 0.05$, according to the LSD test.

${ }^{\mathrm{w}} \mathrm{S}=$ soil application, $\mathrm{F}=$ foliar application (5-L solution/tree).

${ }^{\mathrm{V}} \mathrm{K} 0, \mathrm{~K} 1$, and $\mathrm{K} 2=0 \%, 2.5 \%$, and $5 \% \mathrm{~K}_{2} \mathrm{CO}_{3}$ /tree respectively (10.5 and $21 \mathrm{~g} \mathrm{~K} \cdot \mathrm{L}^{-1} \mathrm{H}_{2} \mathrm{O}, 6.5 \mathrm{~L}$ of solution).

pole (Fig. 1) was used for positioning the spectroradiometer at 80 to $100 \mathrm{~cm}$ above the tree canopy. In addition, each olive tree was georeferenced using the submeter differential DGPS TRIMBLE PRO-XRS (Trimble, Sunnyvale, CA) provided with a TDC-1 unit for further remote sensing analysis. The spectral data were converted into reflectance, which is the ratio of energy reflected off the target to an energy incident on the target, with reference to a barium sulfate standard (Spectralon; Labsphere, North Sutton, NH) before and immediately after each measurement. The hyperspectral range was between 325 to $1075 \mathrm{~nm}$ (1.5-nm bandwidth). However, the reflectance spectra data were noisy at the extremes on the range, and only the measurements between 400 and $900 \mathrm{~nm}$ were analyzed. Previous studies have shown that neighboring wavelengths can frequently provide similar information. Thus, the hyperspectral measurements collected were averaged to represent $5010-\mathrm{nm}$ -

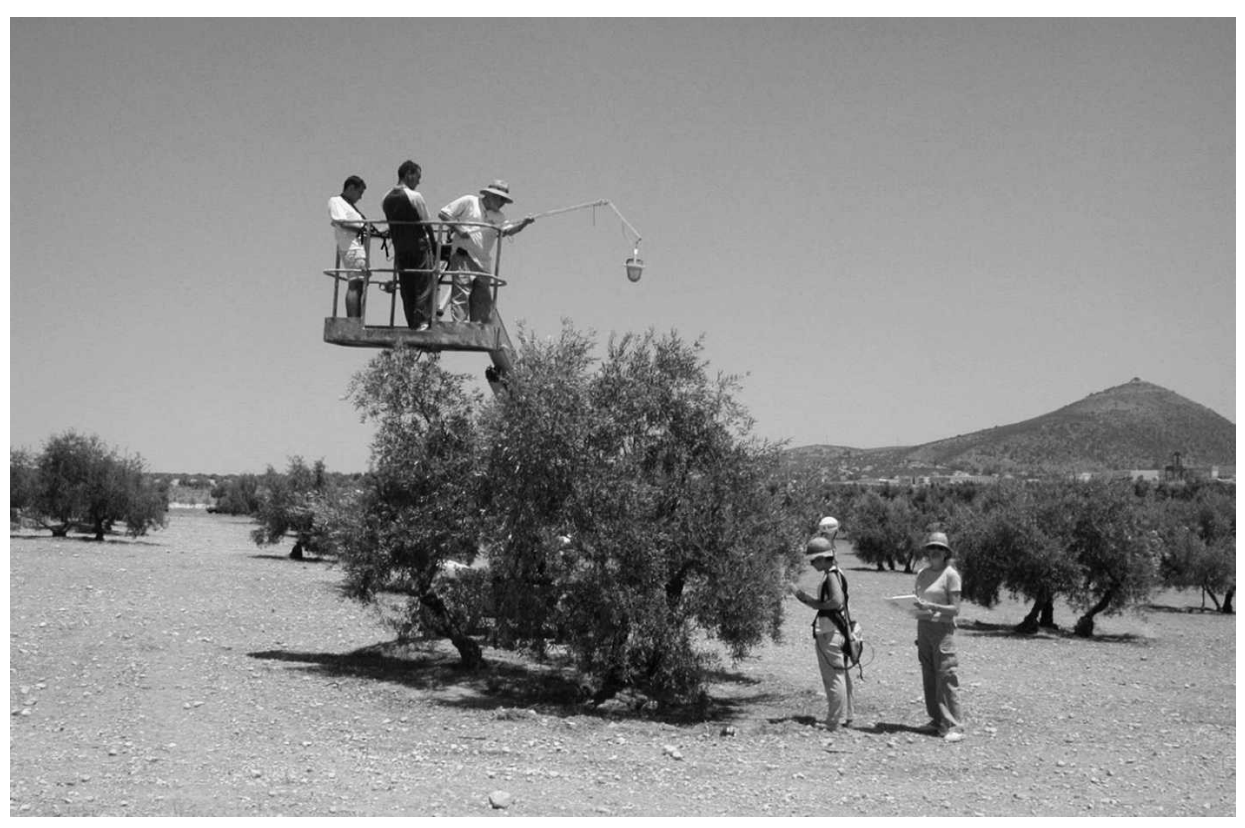

Fig. 1. Measuring olive tree canopy reflectance using a handheld spectroradiometer with a telescopic pole under sunny conditions. wide measurements between 400 and 900 nm (Peña-Barragán et al., 2006; Thenkabail et al., 2004).

Data PRocessing. Discriminant analysis of the canopy hyperspectral data was done using SPSS software (version 11.0; SPSS, Inc., Chicago, IL). Analysis discriminant procedure permitted the setting up of a predictive model of group membership based on characteristics observed in each case. The procedure generated a discriminant function (or a set of them for more than two groups), because the number generated corresponded to the number of groups minus one based on linear combinations of the predictor variables that provided the best discrimination between the groups (Karimi et al., 2005b). The number of discriminant functions that provided a statistically significant among-group variation essentially defined the dimensionality of the discriminant space. This test also measured the difference between groups. To discriminate between different treatments, a set of suitable wavelengths was selected using the stepwise discriminant method of SPSS. This procedure combined forward selection and backward elimination of the variables. Forward selection was used for the inclusion of a variable and backward elimination was used for the removal of variables no longer significant in the model (Karimi et al., 2005a). For this study, a Wilk's lambda test was used to determine the significance of each discriminant function. The values of the Wilk's lambda were indicative of the separability or discriminatory power of spectral wavelengths [i.e., the lower the value of the Wilk's lambda, the greater the spectral differentiation between groups (Thenkabail et al., 2004)]. At each step, the variable that minimized the overall Wilk's lambda was entered. In addition, the minimum partial $\mathrm{F}$ to enter a variable was 3.84 , and 2.71 maximum 
partial $\mathrm{F}$ for removing a variable (more details in Visauta and Martori, 2003).

The stepwise discriminant model was calculated considering every fertilization treatment as a different class. The functions were generated from a sample of cases for which their group membership was known (count data). The functions could then be applied to new cases with measurements for the predictor variables but an unknown group membership. The suitability of the discriminant functions for a given classification was compared using a cross-validation method, which involves the calculation of misclassification matrices. These were calculated by determining the number of wrongly classified groups in any single class. The "one data out" approach for cross-validation was selected from the classification option of the stepwise discriminant analysis to assess the accuracy of the model. In the development of stepwise discriminant models, the data were divided into two parts. The first part was used to develop and construct the model; the second part was used to validate the classification accuracy of the model (Karimi et al., 2005b).

To enhance spectral reflectance differences between the previously described fertilizer treatments, four vegetation indices were also used as follows: NDVI $=\left(\mathrm{R}_{780}-\mathrm{R}_{670}\right)$ / $\left(\mathrm{R}_{780}+\mathrm{R}_{670}\right)$, green-to-red ratio $(\mathrm{G} / \mathrm{R})=\mathrm{R}_{550} / \mathrm{R}_{670}$, NIR-togreen ratio $(\mathrm{NIR} / \mathrm{G})=\mathrm{R}_{780} / \mathrm{R}_{550}$, and $\mathrm{RVI}, \mathrm{NIR} / \mathrm{R}=\mathrm{R}_{780} / \mathrm{R}_{670}$ selected on the basis of an a priori understanding for winter wheat (Schmidhalter et al., 2003).

\section{Results and Discussion}

LEAF NITROGEN CONCENTRATION AND HYPERSPECTRAL REFLECTANCE OF OLIVE TREES AT DIFFERENT NITROGEN RATES UNDER TWO APPLICATION METHODS. Leaf $\mathrm{N}$ content as affected by different $\mathrm{N}$ fertilization treatments is shown in Table 1. Leaf $\mathrm{N}$ concentrations under $\mathrm{N} 1$ and $\mathrm{N} 2$ treatments were higher when $\mathrm{N}$ was applied both to $\mathrm{S}$ and leaves compared with $\mathrm{S}$ applications. Leaf $\mathrm{N}$ concentrations under $\mathrm{N} 1$ and $\mathrm{N} 2$ treatments were higher in 2004, which was an "off" year, than in 2005, classified as an “on” year. Fernández-Escobar et al. (1999) determined a seasonal trend in leaf $\mathrm{N}$ concentration that was highly influenced by alternate bearing, probably as a result of $\mathrm{N}$ consumption by olive fruit during the "on" years. This greater $\mathrm{N}$ accumulation during the nonbearing years was also observed in pistachio trees by Brown et al. (1995).

Leaf $\mathrm{N}$ concentrations under $\mathrm{N} 2$ treatments were significantly higher than those from N1 and N0 in 2004 and 2005 for S and $\mathrm{SF}$ respectively. Leaf $\mathrm{N}$ concentrations under $\mathrm{N} 0$ treatment were below the sufficiency threshold of $1.5 \%$, except for SF treatments in 2004, for which the leaf $\mathrm{N}$ concentration was $1.64 \%$. These olive trees were under nutritional deficiency, indicating that they would not reach an optimum level of productivity as previously reported by Fernández-Escobar (1999). Taking into account that leaf $\mathrm{N}$ concentration from $\mathrm{N} 1$ and $\mathrm{N} 2$ exceeded the fertilization threshold, $\mathrm{N}$ fertilizer would have to be applied only to olive trees with an $\mathrm{N}$ value that does not exceed that threshold. These results are in agreement with those reported by López-Granados et al. (2004) on the clearly patchy distribution of $\mathrm{N}$ depending on leaf nutrient concentration and the nonnecessity of annual and broad $\mathrm{N}$ applications without any criterion.

Mean reflectance curves of $\mathrm{N}$ treatments at Cabra are presented in Fig. 2. The overall shape of hyperspectral reflectance curves for each $\mathrm{N}$ treatment was similar, but the spectral reflectance magnitude and amplitude varied, depending on the application method and treatment of each measurement. Figure 2 shows that certain wavelengths in the visible and NIR regions can be useful in classifying different treatments,

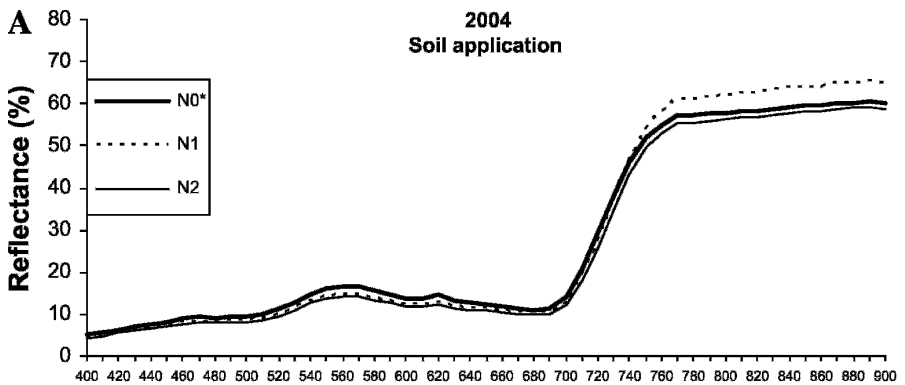

Wavelength $(\mathbf{n m})$

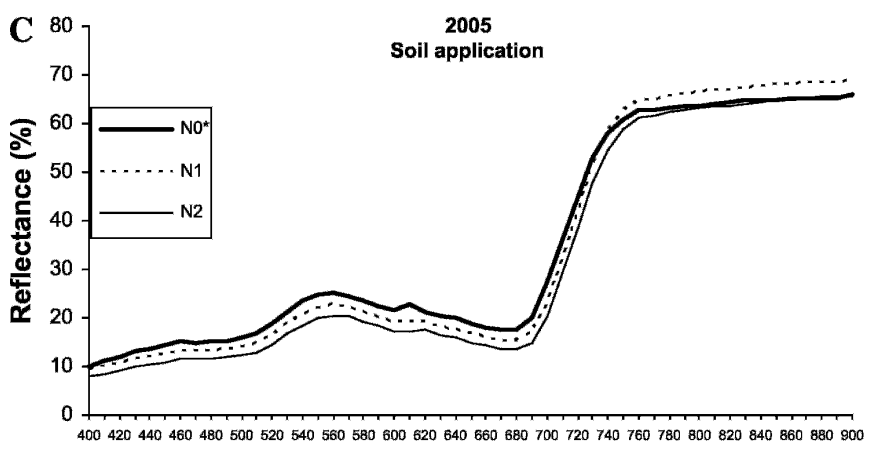

Wavelength (nm)

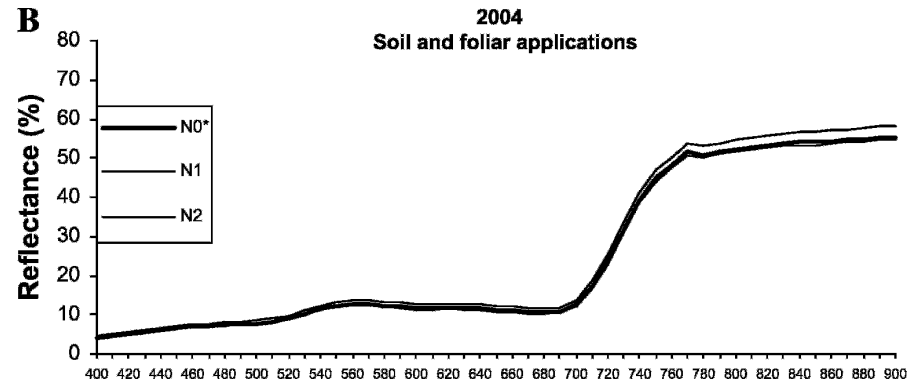

Wavelength (nm)

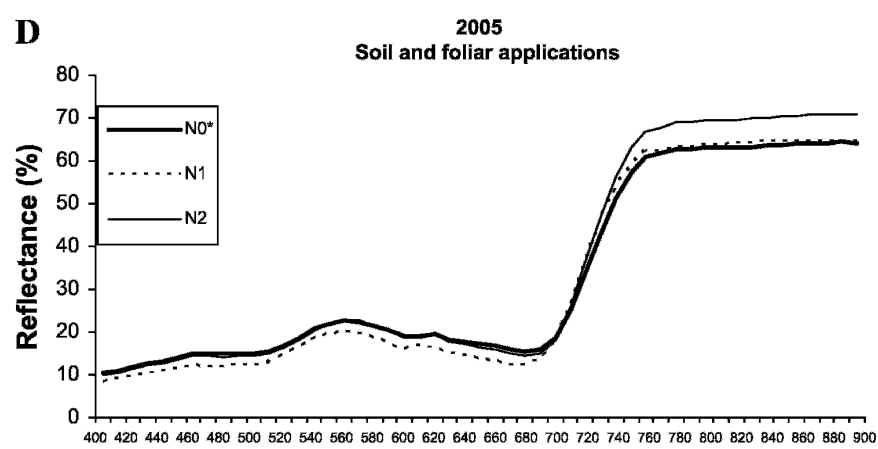

Wavelength (nm)

Fig. 2. (A-D) Mean reflectance curves of olive trees under different nitrogen (N) rates and application methods since 1993. (A) 2004 soil application. (B) 2004 soil and foliar application. (C) 2005 soil application. (D) 2005 soil and foliar application. N0, N1, and N2=0, 0.5, and $1 \mathrm{~kg} \mathrm{~N} /$ tree, respectively. 
showing that there is a potential for separating olive trees under a no-N supply on the basis of their hyperspectral characteristics. Reflectance curves corresponding to $\mathrm{N} 1$ and N2 for S (Fig. 2A, 2C) and SF (Fig. 2B, 2D) applications respectively showed higher reflectance values in the NIR plateau than N0. Thus, there is a potential for discriminating olive trees under nutritional stress from well-nourished ones spectrally.

The nutritional deficiency of olives under N0 corresponds to less reflectance in the NIR region and, by contrast, a higher reflectance in the visible region (from 400-700 nm). Currentseason leaves in July did not tend to be visibly less vigorous compared with those from N1 or N2 treatments. Higher reflectance in the visible wavelengths and lower reflectance in the NIR ones in wheat with $\mathrm{N}$ deficiencies than those with adequate or high $\mathrm{N}$ fertilization have been reported (Hinzman et al., 1986). Fridgen and Varco (2004) also showed a broad reflectance peak centered near $550 \mathrm{~nm}$ in cotton leaves, which is indicative of minimal chlorophyll absorption, with no applied $\mathrm{N}$ compared with other $\mathrm{N}$ rates. Graeff et al. (2001) suggested that reflectance measurements in the visible region do not have any significant changes at light $\mathrm{N}$ deficiency, when no symptoms were visible and the chlorophyll level was higher than $3 \mathrm{mg} \cdot 100 \mathrm{~cm}^{-2}$. This pigment level is only achieved when senescence is induced or when the leaf shows deficiency symptoms.

Although several works have related a lower leaf $\mathrm{N}$ level with lower chlorophyll and a reduced leaf area in low fertility plots, the structural discontinuities (e.g., cell-to-air space ratio), changes in internal cell structure, differences in biomass, or presence of anthocyanin have also been considered important for detecting spectral differences in the NIR domain in Ndeficient plots (Goel et al., 2003; Osborne et al., 2002; Peñuelas and Filella, 1998; Serrano et al., 2000). Reflectance measurements have also demonstrated potential for detecting $\mathrm{N}$ deficient plants in cotton (Bronson et al., 2003), corn (Blackmer et al., 1996), sunflower (Helianthus annuus L.) (Peñuelas et al., 1994), and rice (Xue et al., 2004). Thus, leaf reflectance may be a useful tool for the discrimination of $\mathrm{N}$ status when $\mathrm{N}$ alone is the limiting nutrient.

Discriminant functions obtained from a stepwise selection technique, based on a restricted set of wavelengths or vegetation indices were useful for identifying hyperspectral signatures from olive trees under $\mathrm{N}$ deficiency. Individual wavelengths and vegetation indices were selected to develop the discriminate functions to separate the different $\mathrm{N}$ treatments by using the stepwise discriminant procedure and are shown in Table 2. The values of Wilk's lambda indicated the discriminatory power of every wavelength or vegetation index (i.e., smaller values indicate a higher spectral separability between fertilizer applications). For SF applications, a Wilk's lambda near zero (0.037) was achieved.

Classification results from the discriminant analysis model for different sets of wavelengths and vegetation indices, chosen on the basis of their order of entry in the stepwise discriminant procedure selection to discriminate between $\mathrm{N}$ treatments, are given in Table 2. For $\mathrm{S}$ application, all selected wavelengths were within the NIR domain (from 720-900 nm) in 2004, and in the blue $(400,420$, and $470 \mathrm{~nm})$, red $(610$ and $630 \mathrm{~nm})$, and NIR $(890 \mathrm{~nm})$ regions in 2005 . The NIR/G index was selected in both years. This vegetation index has also been reported by Schmidhalter et al. (2003) as being highly suitable for distinguishing crop biomass and $\mathrm{N}$ content in winter wheat. The overall classifications were $68.5 \%$ and $62 \%$ in 2004 and 2005 respectively. For SF applications, the highest discrimination with an overall classification accuracy of $99.2 \%$ was achieved in 2005. Spectral classification between $\mathrm{N}$ treatments was the result of the function of wavelengths located throughout the spectra (blue region, 420 and $490 \mathrm{~nm}$; green region, $510 \mathrm{~nm}$; red region, $690 \mathrm{~nm}$; and NIR, 710-890 nm). Generally, there were no great differences between the overall correct classification results from the stepwise discriminant analysis and those from the cross-validation. We selected a total of 21 wavelengths (from 50 wavelengths), and the NIR/G and G/R indices, and the one most frequently selected was $890 \mathrm{~nm}$.

The classification matrix for cross-validation is shown in Table 3 . The values put both correctly classified and misclassified cases into the nearest category. It was possible to obtain a correct classification among spectral signatures from the three $\mathrm{N}$ treatments; the nearest category was often misclassified. However, in July 2004, for S and SF applications, some spectral signatures from N0 treatments were misclassified as being those from N2.

LEAF POTASSIUM CONCENTRATION AND HYPERSPECTRAL REFLECTANCE OF OLIVE TREES AT A DIFFERENT POTASSIUM FOLIAR RATE. Leaf $\mathrm{K}$ concentration was higher in 2004, the "off" year, than in 2005, the "on" year (Table 1). Similar results were obtained in alternate-bearing cycles in olives by Fernández-Escobar et al., (1999). Leaf K concentration was also higher in 2004, probably as a result of a higher rainfall. Restrepo (2006) found a significant high correlation between leaf $\mathrm{K}$ concentration in olive trees under different $\mathrm{K}$ supplies and rainfall. When $\mathrm{K}$ was not applied, leaf $\mathrm{K}$ content was below the sufficiency threshold of $0.8 \%$. These results indicated that only $\mathrm{K} 0$ olives should receive $\mathrm{K}$ fertilizer to optimize the

Table 2. Stepwise discriminant results for wavelengths and vegetation indices selected for nitrogen $(\mathrm{N})$ and potassium $(\mathrm{K})$ treatments in olive trees.

\begin{tabular}{|c|c|c|c|c|c|c|c|}
\hline $\begin{array}{l}\text { Location } \\
\text { (nutrient) }\end{array}$ & $\begin{array}{l}\text { Application } \\
\text { method }\end{array}$ & Year & $\begin{array}{l}\text { Wavelength }(\mathrm{nm}) \text { and } \\
\text { vegetation indices }\end{array}$ & $\begin{array}{l}\text { Wilk's } \\
\text { lambda }\end{array}$ & Exact $\mathrm{F}$ & $\begin{array}{c}\text { Overall } \\
\text { classification } \\
(\%)\end{array}$ & $\begin{array}{c}\text { Cross-validation } \\
(\%)\end{array}$ \\
\hline \multirow[t]{3}{*}{ Cabra, Spain (N) } & Soil & 2004 & $900,830,720, \mathrm{NIR} / \mathrm{G}^{\mathrm{z}}, \mathrm{G} / \mathrm{R}^{\mathrm{z}}$ & 0.449 & 19.017 & 68.5 & 65.0 \\
\hline & Soil and & 2004 & $670,430,690,510,410,760,770,830,650,780$ & 0.751 & 9.987 & 72.5 & 70.5 \\
\hline & foliar & 2005 & $890,740,420,830,760,510,490,690,710$ & 0.037 & 51.473 & 99.2 & 97.5 \\
\hline Lucena, Spain (K) & Foliar & 2004 & $550,570,770,780,890, \mathrm{NDVI}^{z}$ & 0.268 & 69.646 & 94.4 & 94.4 \\
\hline
\end{tabular}

${ }^{\mathrm{Z}}$ Near-infrared-to-green ratio $(\mathrm{NIR} / \mathrm{G})=\mathrm{R}_{780} / \mathrm{R}_{550}$, green-to-red ratio $(\mathrm{G} / \mathrm{R})=\mathrm{R}_{550} / \mathrm{R}_{670}$, normalized difference vegetation index $(\mathrm{NDVI})=$ $\left(\mathrm{R}_{780}-\mathrm{R}_{670}\right) /\left(\mathrm{R}_{780}+\mathrm{R}_{670}\right)$. 
Table 3. Classification matrix (measured in percent) obtained from the discriminant analysis procedure for count and cross-validation using wavelengths and vegetation indices for nitrogen $(\mathrm{N})$ application in olive trees.

\begin{tabular}{|c|c|c|c|c|c|c|}
\hline \multirow{3}{*}{$\begin{array}{l}\text { Application } \\
\text { method }\end{array}$} & \multirow[b]{3}{*}{ Year } & \multirow{3}{*}{$\begin{array}{c}\text { Classification } \\
\text { method }\end{array}$} & \multicolumn{4}{|c|}{$\mathrm{N}$ treatment } \\
\hline & & & \multirow[b]{2}{*}{ Actual } & \multicolumn{3}{|c|}{ Predicted } \\
\hline & & & & No & $\mathrm{N} 1$ & $\mathrm{~N} 2$ \\
\hline \multirow[t]{12}{*}{ Soil } & \multirow[t]{6}{*}{2004} & \multirow[t]{3}{*}{ Count } & $\mathrm{N} 0^{\mathrm{z}}$ & 76 & 5 & 19 \\
\hline & & & N1 & 5 & 70 & 25 \\
\hline & & & $\mathrm{N} 2$ & 19 & 21 & 60 \\
\hline & & \multirow[t]{3}{*}{ Cross-validation } & No & 76 & 5 & 19 \\
\hline & & & N1 & 5 & 70 & 25 \\
\hline & & & $\mathrm{N} 2$ & 19 & 21 & 60 \\
\hline & \multirow[t]{6}{*}{2005} & \multirow[t]{3}{*}{ Count } & No & 85 & 15 & 0 \\
\hline & & & N1 & 15 & 47 & 38 \\
\hline & & & $\mathrm{N} 2$ & 8 & 17 & 75 \\
\hline & & \multirow[t]{3}{*}{ Cross-validation } & No & 85 & 15 & 0 \\
\hline & & & N1 & 15 & 47 & 38 \\
\hline & & & N2 & 8 & 25 & 67 \\
\hline \multirow{12}{*}{$\begin{array}{l}\text { Soil and } \\
\text { foliar }\end{array}$} & \multirow[t]{6}{*}{2004} & \multirow[t]{3}{*}{ Count } & N0 & 68 & 0 & 32 \\
\hline & & & N1 & 0 & 100 & 0 \\
\hline & & & $\mathrm{N} 2$ & 36 & 0 & 64 \\
\hline & & \multirow[t]{3}{*}{ Cross-validation } & No & 64 & 0 & 36 \\
\hline & & & N1 & 0 & 100 & 0 \\
\hline & & & $\mathrm{N} 2$ & 38 & 0 & 62 \\
\hline & \multirow[t]{6}{*}{2005} & \multirow[t]{3}{*}{ Count } & No & 98 & 0 & 2 \\
\hline & & & N1 & 0 & 100 & 0 \\
\hline & & & $\mathrm{N} 2$ & 0 & 0 & 100 \\
\hline & & \multirow[t]{3}{*}{ Cross-validation } & N0 & 98 & 0 & 2 \\
\hline & & & N1 & 0 & 100 & 0 \\
\hline & & & N2 & 0 & 0 & 100 \\
\hline
\end{tabular}

${ }_{\mathrm{z}} \mathrm{N} 0, \mathrm{~N} 1$, and $\mathrm{N} 2=0,0.5$, and $1 \mathrm{~kg} \mathrm{~N} /$ tree, respectively.

fertilization practices. This may be particularly important in alleviating the low productivity associated with $\mathrm{K}$ deficiencies in dry lands, because these are the main agronomic circumstances in the Mediterranean area, where many olive orchards are K deficient (Fernández-Escobar et al., 1994). There were no significant differences between $\mathrm{K} 1$ and $\mathrm{K} 2$ applications in either year. Restrepo (2006) tested $5 \mathrm{~K}$ salts at $0 ; 2.5 \%$ and $5 \% /$ tree for 8 years. The dosage of $5 \%$ did not show any significant differences when compared with $2.5 \%$ relative to $\mathrm{K}$ leaf content, $\mathrm{K}$ fruit content, or yield. This indicates that $5 \%$ applications of $\mathrm{K}$ do not produce changes in $\mathrm{K}$ leaf content, so they are not recommended. Therefore, only reflectance data for $\mathrm{K} 0$ and $\mathrm{K} 1$ are presented.

Mean reflectance curves for $\mathrm{K}$ treatments are shown in Fig. 3. This figure reveals consistent differences in reflectance values for $\mathrm{K} 0$ and $\mathrm{K} 1$ treatments, the highest reflectance readings in the NIR domain occurring in both years. It also reveals that particular wavelengths in the visible region and some more in the NIR region could be useful for classifying those treatments. Thus, a total of 10 wavelengths (from 50 wavelengths) and the NDVI index were selected for discriminating spectral signatures from olive trees with low and high leaf $\mathrm{K}$ concentrations. They were chosen on the basis of their order of entry in the stepwise discriminant procedure selection and are shown in Table 2. In 2004, $75 \%$ of the selected wavelengths were located in the NIR region $(770-890 \mathrm{~nm})$. The rest of the selected wavelengths were in the green region of

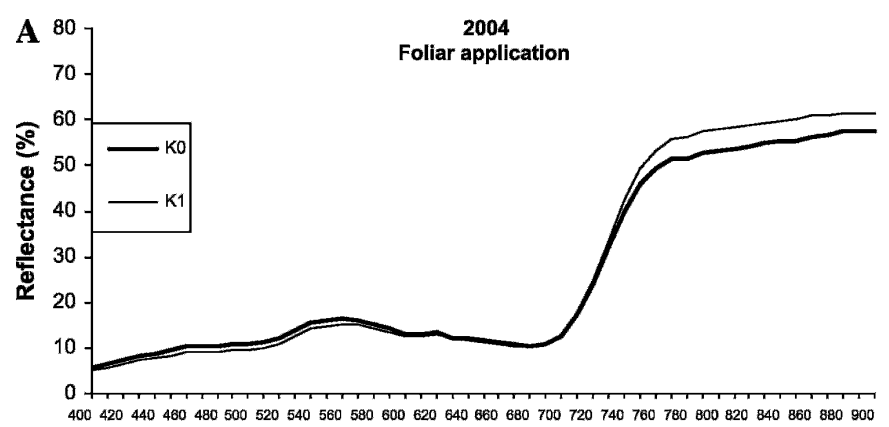

Wavelength (nm)

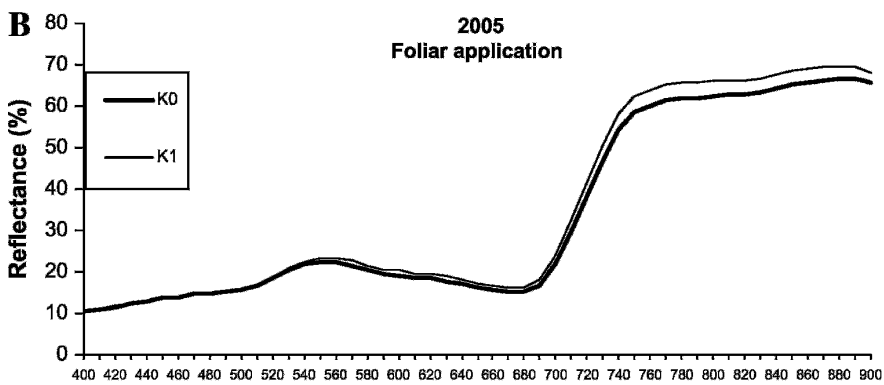

Wavelength (nm)

Fig. 3. (A, B) Mean reflectance curves of olive trees under potassium (K) foliar applications since 1997. (A) 2004. (B) 2005. K0 and $\mathrm{K} 1=0 \%$ and $2.5 \%$ $\mathrm{K}_{2} \mathrm{CO}_{3}$ /tree, respectively.

the spectrum $(550-570 \mathrm{~nm})$. In 2005 , wavelengths located in the NIR region were again selected. The normalized difference vegetation index has been widely cited to distinguish crop growth, and $\mathrm{N}$ and water stresses (Scharf et al., 2002; Thenkabail et al., 2000). However, to our knowledge, there has not been any reference to discrimination of $\mathrm{K}$ deficiency in olive trees by NDVI. The best classification result was obtained in July 2004, with an overall accuracy of around 95\%. The classification matrix for cross-validation is shown in Table 4. The values put both correctly classified and misclassified cases into the other category.

Several works have reported on $\mathrm{K}$ requirements and their spatial distribution in olive orchards (Fernández-Escobar et al., 1999; Hartmann et al., 1966; López-Granados et al., 2004; Restrepo, 2006), prune trees (Prunus domestica L. 'French') (Weinbaum et al., 1994), and fig (Ficus carica L.) (Brown, 1994). Ponzoni and Gonçalves (1999) demonstrated that

Table 4. Classification matrix (measured in percent) obtained from the discriminant analysis procedure for count and cross-validation using wavelengths and vegetation indices for foliar potassium $(\mathrm{K})$ application in olive trees.

\begin{tabular}{lcccr}
\hline & & \multicolumn{3}{c}{ K treatment } \\
\cline { 3 - 5 } Year & Classification method & Actual $^{\mathrm{z}}$ & $\mathrm{K} 0$ & $\mathrm{~K} 1$ \\
\cline { 3 - 5 } 2004 & Count & $\mathrm{K} 0$ & 95 & 5 \\
& \multirow{2}{*}{ Cross-validation } & $\mathrm{K} 1$ & 6.3 & 94 \\
& & $\mathrm{~K} 0$ & 95 & 5 \\
& \multirow{3}{*}{ Count } & $\mathrm{K} 1$ & 6 & 94 \\
& \multirow{3}{*}{ Cross-validation } & $\mathrm{K} 0$ & 73 & 27 \\
& & $\mathrm{~K} 1$ & 21 & 79 \\
& & $\mathrm{~K} 0$ & 71 & 29 \\
& & $\mathrm{~K} 1$ & 24 & 76
\end{tabular}

${ }^{\mathrm{z}} \mathrm{K} 0$ and $\mathrm{K} 1=0 \%$ and $2.5 \% \mathrm{~K}_{2} \mathrm{CO}_{3}$, respectively. 
symptoms related to $\mathrm{K}$ deficiency were spectrally detected in the visible region when working in eucalyptus leaves. Fridgen and Varco (2004) reported that increasing $\mathrm{K}$ nutrition did not have a consistent effect on total chlorophyll content in cotton leaves and concluded that $\mathrm{N}$ and $\mathrm{K}$ deficiencies can be detected by leaf reflectance in the visible and NIR ranges. In our study, the relationship between the leaf $\mathrm{K}$ concentration and corresponding spectral measurements has demonstrated that it is possible to discriminate olive trees with $\mathrm{K}$ deficiencies spectrally.

\section{Conclusion}

Induction of $\mathrm{N}$ or $\mathrm{K}$ nutritional deficiency for more than 10 years in olive trees resulted in different leaf nutrient status, which affected hyperspectral reflectance curves. Spectral signatures from olives with leaf $\mathrm{N}$ or $\mathrm{K}$ concentrations below the fertilization threshold exhibited consistent differences in magnitude in both the visible and NIR regions for discriminating between $\mathrm{N}$ or $\mathrm{K}$ treatments. The study resulted in recommending 26 wavelengths, and the NIR/G, G/R, and NDVI indices to discriminate between $\mathrm{N}$ or $\mathrm{K}$ treatments, with those most frequently selected being 830 and $890 \mathrm{~nm}$ for both nutrients. Discriminant analysis showed itself to be a useful tool to discriminate spectral signatures of $\mathrm{N}$ - or K-deficient olive trees. Hyperspectral differences may be attributed to variation in the leaf $\mathrm{N}$ or $\mathrm{K}$ concentration. These results offer opportunities for the remote sensing detection of olive trees under $\mathrm{N}$ or $\mathrm{K}$ deficiency, compared with well-nourished ones, using airborne hyperspectral sensors. By knowing the olive tree location with leaf $\mathrm{N}$ or $\mathrm{K}$ concentration in the most spectrally suitable region, a program of site-specific fertilization could be designed for extensive areas, thus opening up the possibility of a consistent reduction in fertilization with evident economic and environmental benefits, especially a decrease in $\mathrm{N}$ leaching and groundwater pollution.

\section{Literature Cited}

Alchanatis, V. and Z. Schmilovitch. 2005. In-field assessment of single leaf nitrogen status by spectral reflectance measurements. Precision Agr. 6:25-39.

Arquero, O. 2004. Efecto del potasio sobre el crecimiento y estado hídrico del olivo, Universidad de Córdoba, Spain. PhD diss.

Benton Jones, J. 1985. Soil testing and plant analysis: Guides to the fertilization of horticultural crops. HortScience 7:645-648.

Blackmer, T.M., J.S. Schepers, G.E. Varvel, and E.A. Walter-Shea. 1996. Nitrogen deficiency detection using reflected shortwave radiation from irrigated corn canopies. Agron. J. 88:1-5.

Bronson, K.F., T.T. Chua, J.D. Booker, J.W. Keeling, and J.R. Lascano. 2003. In-season nitrogen status sensing in irrigated cotton: II. Leaf nitrogen and biomass. Soil Sci. Soc. Amer. J. 67:1439-1448.

Brown, P.H. 1994. Seasonal variations of fig (Ficus carica L.) leaf nutrient concentrations. HortScience 29:871-873.

Brown, P.H., S.A. Weinbaum, and G.A. Picchioni. 1995. Alternate bearing influences annual nutrient consumption and the total nutrient content of mature pistachio trees. Trees (Berl.) 9:158-164.

Elmore, A.J., J.F. Mustard, S.J. Manning, and D.B. Lobell. 2000. Quantifying vegetation change in semiarid environments: Precision and accuracy of spectral mixture analysis and the normalized difference vegetation index. Remote Sensing Environ. 73:87-102.

Fernández-Escobar, R. 1999. Fertilización, p. 247-265. In: D. Barranco, R. Fernández-Escobar, and L. Rallo (eds.). El cultivo del olivo. Mundi-Prensa, Madrid, Spain.
Fernández-Escobar, R., G. Beltrán, M.A. Sánchez-Zamora, J. GarcíaNovelo, M.P. Aguilera, and M. Uceda. 2006. Olive oil quality decreases with nitrogen over-fertilization. HortScience 41: 215-219.

Fernández-Escobar, R., T. García-Barragán, and M. Benlloch. 1994. Estado nutritivo de las plantaciones de olivar en la provincia de Granada. Información Técnica Económica Agraria 90:39-49.

Fernández-Escobar, R., R. Moreno, and M. García-Creus. 1999. Seasonal changes of mineral nutrients in olive leaves during the alternate-bearing cycle. Sci. Hort. 82:25-45.

Ferwerda, J.G., A.K. Skidmore, and O. Mutanga. 2005. Nitrogen detection with hyperspectral normalized ratio indices across multiple plant species. Int. J. Remote Sens. 26:4083-4095.

Fridgen, J.L. and J.J. Varco. 2004. Dependency of cotton leaf nitrogen, chlorophyll, and reflectance on nitrogen and potassium availability. Agron. J. 96:63-69.

Girma, K.J., J. Mosali, W.R. Raun, K.W. Freeman, K.L. Martin, J.B. Solie, and M.L. Stone. 2005. Identification of optical spectral signatures for detecting cheat and ryegrass in winter wheat. Crop Sci. 45:477-485.

Goel, P.K., S.O. Prasher, R.M. Patel, J.A. Landry, R.B. Bonnel, and A.A. Viau. 2003. Classification of hyperspectral data by decision trees and artificial neural networks to identify weed stress and nitrogen status of corn. Computers Electronics Agr. 39: 67-93.

Graeff, S., D. Steffens, and S. Schubert. 2001. Use of reflectance measurements for the early detection of $\mathrm{N}, \mathrm{P}, \mathrm{Mg}$, and Fe deficiencies in Zea mays L. J. Plant Nutr. Soil Sci. 164:445-450.

Haboudane, D., J.R. Miller, N. Tremblay, P.J. Zarco-Tejada, and L. Dextraze. 2002. Integrated narrow-band vegetation indices for prediction of crop chlorophyll content for application to precision agriculture. Remote Sensing Environ. 81:416-426.

Hansen, P.M. and J.K. Schjoerring. 2003. Reflectance measurement of canopy biomass and nitrogen status in wheat crops using normalized difference vegetation indices and partial least squares regression. Remote Sensing Environ. 86:542-553.

Hartmann, H.T. 1958. Some responses of the olive to nitrogen fertilizers. Proc. Amer. Soc. Hort. Sci. 72:257-266.

Hartmann, H.T., K. Uriu, and O. Lilleland. 1966. Olive nutrition, p. 252-261. In: N.F. Childers (ed.). Fruit nutrition. Horticultural Publications, New Brunswick, NJ.

Hinzman, L.D., M.E. Bauer, and C.S.T. Daughtry. 1986. Effects of nitrogen fertilization on growth and reflectance characteristics of winter wheat. Remote Sensing Environ. 19:47-61.

Jackson, R.D. and A.R. Huete. 1991. Interpreting vegetation indices. Prev. Vet. Med. 11:185-200.

Jordan, C.F. 1969. Derivation of leaf area index from quality of light on the forest floor. Ecology 50:663-666.

Karimi, Y., S.O. Prasher, H. Mcnaim, R.B. Bonnell, P. Dutilleul, and P.K. Goel. 2005a. Classification accuracy of discriminant analysis, neural networks and decision trees for weed and nitrogen stress detection in corn. Trans. Amer. Soc. Agr. Eng. 48:1261-1268.

Karimi, Y., S.O. Prasher, H. Mcnaim, R.B. Bonnell, P. Dutilleul, and P.K. Goel. 2005b. Discriminant analysis of hyperspectral data for assessing water and nitrogen stresses in corn. Trans. Amer. Soc. Agr. Eng. 48:805-813.

Koger, C.H., D.R. Shaw, K.N. Reddy, and L.M. Bruce. 2004. Detection of pitted morningglory (Ipomoea lacunosa) with hyperspectral remote sensing. II. Effects of vegetation ground cover and reflectance properties. Weed Sci. 52:230-235.

López-Granados, F., M. Jurado-Expósito, S. Álamo, and L. GarcíaTorres. 2004. Leaf nutrient spatial variability and site-specific fertilization maps within olive (Olea europaea L.) orchards. Eur. J. Agron. 21:209-222.

Marín, L. and R. Fernández-Escobar. 1997. Optimization of nitrogen fertilization in olive orchards, p. 411-414. In: J. Montañés and L. Monge (eds.). On mineral nutrition of deciduous fruit trees. Proc. 3rd Intl. Symp, Zaragoza, Spain. 
Osborne, S.L., J.S. Schepers, D.D. Francis, and M.R. Schlemmer. 2002. Detection of phosphorus and nitrogen deficiencies in corn using spectral radiance measurements. Agron. J. 94:1215-1221.

Peña-Barragán, J.M., F. López-Granados, M. Jurado-Expósito, and L. García-Torres. 2006. Spectral discrimination of Ridolfia segetum and sunflower as affected by phenological stage. Weed Res. 46: $10-21$.

Peñuelas, J. and I. Filella. 1998. Visible and near-infrared reflectance techniques for diagnosing plant physiological status. Trends Plant Sci. 3:151-155.

Peñuelas, J., J.A. Gamon, A.L. Fredeen, J. Merino, and C.B. Field. 1994. Reflectance indices associated with physiological changes in nitrogen- and water-limited sunflower leaves. Remote Sensing Environ. 48:135-146.

Ponzoni, F.J. and J.L.M. Gonçalves. 1999. Spectral features associated with nitrogen, phosphorus, and potassium deficiencies in Eucalyptus saligna seedling leaves. Int. J. Remote Sens. 20:2249-2264.

Restrepo, H. 2006. Influencia de factores fisiológicos y ambientales en la nutrición potásica del olivo, Universidad de Córdoba, Spain. $\mathrm{PhD}$ diss.

Rouse, J.W., R.H. Haas, J.A. Schell, and D.W. Deering. 1973. Monitoring vegetation systems in the Great Plains with ERTS, p. 309-317. In: NASA Technical Reports Server (NTRS), NASA SP-351. Proc. 3rd ERTS Symp., National Aeronautics and Space Administration, Washington, DC.

Salisbury, J.W. 1999. Environmental factors affecting reflectance measurements, p. 2-9. In: Spectral measurements field guide. Rpt. no. ADA362372, 90. Defense Technical Information Center, Fort Belvoir, VA.

Scharf, P.C., J.P. Schmidt, N.R. Kitchen, K.A. Sudduth, S.Y. Hong, J.A. Lory, and J.G. Davis. 2002. Remote sensing for nitrogen management. J. Soil Water Conservation 57:518-524.

Schmidhalter, U., S. Jungert, C. Bredemeier, R. Gutser, R. Manhart, B. Mistele, and G. Gerl. 2003. Field-scale validation of a tractor based multispectral crop scanner to determine biomass and nitrogen uptake of winter wheat, p. 615-620. In: J.V. Stattford and A. Werner (eds.). Precision agriculture. Wageningen Academic Publishers, Wageningen, The Netherlands.

Schmidt, K.S. and A.K. Skidmore. 2003. Spectral discrimination of vegetation types in coastal wetland. Remote Sensing Environ. 85: 92-108.

Serrano, L., I. Filella, and J. Peñuelas. 2000. Remote sensing of biomass and yield of winter wheat under different nitrogen supplies. Crop Sci. 40:723-730.

Slaughter, D.C., W.T. Lanini, and D.K. Giles. 2004. Discriminating weeds from processing tomato plants using visible and near-infrared reflectance. Trans. Amer. Soc. Agr. Eng. 47:1907-1911.

Thenkabail, P.S., E.A. Enclona, M.S. Ashton, and B. Van Der Meer. 2004. Accuracy assessments of hyperspectral wavebands performance of vegetation analysis applications. Remote Sensing Environ. 91:354-376

Thenkabail, P.S., R.B. Smith, and E. De-Pauw. 2000. Hyperspectral vegetation indices for determining agricultural crop characteristics. Remote Sensing Environ. 71:158-182.

Visauta, B. and J.C. Martori. 2003. Análisis discriminante, p. 123-162. In: Análisis estadístico con SPSS para Windows, Vol. II. McGrawHill Interamericana de España, Aravaca Madrid, Spain.

Wang, D., F.E. Dowell, and R.E. Lacey. 1999. Single wheat kernel colour classification using neural networks. Trans. Amer. Soc. Agr. Eng. 42:233-240.

Weinbaum, S.A., F.J.A. Niederholzer, S. Ponchner, R.C. Rosecrance, R.M. Carlson, A.C. Whittlesey, and T.T. Muraoka. 1994. Nutrient uptake by cropping and defruited field-grown "French" prune trees. J. Amer. Soc. Hort. Sci. 119:925-930.

Xue, L., W. Cao, W. Luo, T. Dai, and Y. Zhu. 2004. Monitoring leaf nitrogen status in rice canopy spectral reflectance. Agron. J. 96: $135-142$. 